\title{
HREM studies of complex uranium oxides containing molybdenum and tungsten
}

\author{
Margareta Sundberg $\left({ }^{1}\right)$ and Valeri Tabachenko $\left({ }^{2}\right)$
}

( $\left.{ }^{1}\right)$ Department of Inorganic Chemistry, Arrhenius Laboratory, Stockholm University, S-10691 Stockholm, Sweden

$\left({ }^{2}\right)$ X-ray Laboratory, Department of Inorganic Chemistry, Faculty of Chemistry, Moscow State University, U.S.S.R.

(Received October 29, 1990; accepted January 04, 1991)

\begin{abstract}
Résumé. - La microscopie haute résolution, la diffraction $\mathrm{X}$ sur poudres et sur monocristal ont été utilisées pour caractériser les phases formées par réactions à l'état solide dans le systeme $\mathrm{UO}_{2}-$ $\mathrm{MoO}_{2}-\mathrm{MoO}_{3}-\mathrm{WO}_{3}$. Quelques phases sont décrites comme des membres d'une série homologue construite avec des feuillets de différentes épaisseurs de type $\mathrm{ReO}_{3}$. D'après les résultats antérieurs en diffraction $\mathrm{X}$, ces feuillets sont connectés par des atomes $\mathrm{U}$ et $\mathrm{O}$ de telle sorte que de fins feuillets plissés de bipyramides pentagonales $\mathrm{UO}_{7}$, reliées par des arêtes, sont formés. La formule générale est UO $\cdot M_{n} \mathrm{O}_{3 n+1}, n$ est le nombre d'octaèdres selon un feuillet $\mathrm{ReO}_{3}$. Des structures formées de feuillets de type $\mathrm{ReO}_{3}$ ordonné et de largeur $n=2 ; 4$ et 5 ont été examinés. De manière similaire, cet ensemble de phases peut être considéré comme une intercroissance de structure de type $\mathrm{UVO}_{5}$ avec les feuillets $\mathrm{ReO}_{3}$ de différentes épaisseurs. Dans les phases pour lesquelles U est remplacé par Mo ou W, les feuillets $\mathrm{ReO}_{3}$ sont connectés par des octaèdres $\mathrm{MoO}_{6}$ de telle sorte que des tunnels à 6 côtés sont formés et dans lesquels existent des chaines d'atomes -O -U -O -U. Enfin, un arrangement presque ordonné de bipyramides hexagonales $\mathrm{UO}_{8}$ et d'octaèdres $\mathrm{ReO}_{3}$ connecte les feuillets $\mathrm{ReO}_{3}$. La formule générale pour cette série homologue est $\mathrm{U}_{1-x} \square_{x} \mathrm{O} \cdot m \mathrm{MO}_{3}$, où $\square$ est une lacune et $m=$ $2 n+1$ ( $n$ : nombre d'octaèdres $M \mathrm{O}_{6}$ formant le feuillet $\mathrm{ReO}_{3}$ ). Le réseau base de ces structures peut être considéré comme l'intercroissance de feuillets de type HTB (Bronze de Tungstène hexagonal), d'une rangée de tunnels vides avec les feuillets $\mathrm{ReO}_{3}$ d'épaisseurs différentes. Les phases construites à partir de feuillets $\mathrm{ReO}_{3}$ avec $n=3,4$ et 5 et avec une occupation moitié des atomes $\mathrm{U}(x=0,5)$ dans les tunnels à 6 côtés ont été étudiées; de même que $\mathrm{UMO}_{5} \mathrm{O}_{16}$ dont l'occupation des positions $\mathrm{U}$ est complète avec les feuillets $\mathrm{ReO}_{3}$ de 2 octaèdres d'épaisseur. La structure $\mathrm{U}_{0,5}(\mathrm{Mo}, \mathrm{W})_{9} \mathrm{O}_{28}$ possède un ordre sur les lacunes. Cette série est voisine des structures d'intercroissance de Bronzes de Tungstene (ITB).
\end{abstract}

\footnotetext{
Abstract . - HREM, X-ray powder and single-crystal diffraction techniques were used to characterize phases formed in the $\mathrm{UO}_{2}-\mathrm{MoO}_{2}-\mathrm{MoO}_{3}-\mathrm{WO}_{3}$ system by solid state reaction. Some of the phases studied can be described as members of a homologous series of structures built up of $\mathrm{ReO}_{3}-$ type slabs of different widths. According to previous X-ray studies, these slabs are connected by $U$ and $\mathrm{O}$ atoms so that thin pleated slabs of edge sharing pentagonal $\mathrm{UO}_{7}-$ bipyramids are formed. The general formula is UO $\cdot M_{n} \mathrm{O}_{3 n+1}$, where $n=$ number of octahedra across the $\mathrm{ReO}_{3}-$ type slab. Structures containing ordered $\mathrm{ReO}_{3}$ - type slabs of $n=2,4$ and 5 widths have been examined. Alternatively, this set of phases can be regarded as intergrowths of an $\mathrm{UVO}_{5}-$ type structure with $\mathrm{ReO}_{3}-$ type slabs of different widths. In phases where $\mathrm{U}$ is replaced by $\mathrm{Mo}$ or $\mathrm{W}$, the $\mathrm{ReO}_{3}$ - type slabs are connected by $\mathrm{MoO}_{6}$ - octahedra so that six-sided tunnels are formed, in which strings of -O-U-O-U.
} 
atoms are found. Hence, an almost planar ordered arrangement of hexagonal $\mathrm{UO}_{8}-$ bipyramids and $\mathrm{MoO}_{6}-$ octahedra connects the $\mathrm{ReO}_{3}$ - type slabs. The general formula of this homologous series of phases is $\mathrm{U}_{1-x} \square_{x} \mathrm{O} \cdot m M \mathrm{O}_{3}$, where $\square=$ vacancy and $m=2 n+1\left(n=\right.$ number of $M \mathrm{O}_{6}-$ octahedra across the $\mathrm{ReO}_{3}$ - type slab). The basic network structure can be considered as an intergrowth of slabs of HTB- elements (hexagonal tungsten bronze), one tunnel row wide, with $\mathrm{ReO}_{3}$ - type slabs of different widths. Phases built up of $\mathrm{ReO}_{3}$ - type slabs with $n=3,4$ and 5 with half occupancy of $U$ atoms $(x=0.5)$ in the six-sided tunnels have been studied, as well as $\mathrm{UMo}_{5} \mathrm{O}_{16}$ with full occupancy of all $\mathrm{U}$ positions and with $\mathrm{ReO}_{3}$-type slabs two octahedra wide. The $\mathrm{U}_{0.5}(\mathrm{Mo}, \mathrm{W})_{9} \mathrm{O}_{28}$ structure contained ordered vacancies. This series is closely related to the intergrowth tungsten bronze (ITB) structures.

\section{Introduction.}

Previous X-ray studies of complex uranium molybdenum oxides [1-6], have shown that a series of phases related to the orthorhombic $\beta-\mathrm{UMo}_{2} \mathrm{O}_{8}$ structure can be prepared. The structures can be described as built up of corner-sharing $\mathrm{MO}_{6}$-octahedra that form slabs of $\mathrm{ReO}_{3}-$ type. The slabs extend indefinitely in two dimensions, while the width of the slabs is finite but variable. In the $\beta-\mathrm{UMo}_{2} \mathrm{O}_{8}$ structure [7] (Fig. 1a) the width of the $\mathrm{ReO}_{3}-$ type slab corresponds to two $M \mathrm{O}_{6}-$ octahedra. The slabs are mutually linked by -U-O-U-O-strings parallel to the short $c$-axis, of the structure so that cornersharing pentagonal $\mathrm{UO}_{7}-$ bipyramids are formed. Along the $b=$ axis, the slabs can be described as linked by pleated edge-sharing chains of pentagonal $\mathrm{UO}_{7}-$ bipyramids. The unit cell dimensions given by Cremers et al. [7] are: $a=20.076, b=7.323, c=4.1164 \AA$.

Partial substitution of molybdenum for uranium in $\beta-\mathrm{UMo}_{2} \mathrm{O}_{8}$ creates vacancies in the structure so as to maintain charge balance. Such substitutions have been made to form the $\mathrm{UMo}_{10} \mathrm{O}_{32}$ and $\alpha-\mathrm{U}_{3} \mathrm{Mo}_{20} \mathrm{O}_{64}$ phases. X-ray structure determinations of these phases showed that vacancies were regularly distributed along the linkage plane between the $\mathrm{ReO}_{3}$-type slabs. The $\mathrm{UMo}_{10} \mathrm{O}_{32}$ structure [5] is shown in figure 1b. As can be seen in figure 1, both structures consist of $\mathrm{ReO}_{3}$-type slabs two $\mathrm{MO}_{6}$-octahedra in width, but the atom arrangements between the slabs are different. In figure $1 \mathrm{~b}$, where the $U$ atoms are partly replaced by Mo atoms and vacancies, $\mathrm{MoO}_{6}$-octahedra connect the $\mathrm{ReO}_{3}$-type slabs by cornersharing so that six-sided tunnels are formed, where strings of alternating $U$ and $O$ atoms can enter. The six-sided tunnels are thus transformed into rows of cornersharing hexagonal $\mathrm{UO}_{8}$-bipyramids along the short crystal axis. In the $\mathrm{UMo}_{10} \mathrm{O}_{32}$ structure, only half of the available uranium positions are occupied by uranium atoms. The length of the $b$-axis in figure $1 \mathrm{a}$ is the same as that of the $c$-axis in figure $1 \mathrm{~b}$, while the $a$-axis in figure $1 \mathrm{a}$ is twice that in figure $1 \mathrm{~b}$.

High resolution electron microscopy (HREM) technique has previously been used to investigate order and disorder in a few complex oxide compounds, where $U$ has been partly replaced by $\mathrm{Mo}$ and $\mathrm{W}$. The structure models of $\mathrm{U}_{4} \mathrm{O}_{14}$ and $\mathrm{U}_{5} \mathrm{O}_{17}$, where $M=$ "W", have been derived from HREM images. These phases have been described as two members $(n=4$ and $n=5)$ of the homologous series $\mathrm{U}_{n} \mathrm{O}_{3 n+2}, M=$ "W" (8). The defect structures of " $\mathrm{UW}_{5} \mathrm{O}_{17}$ " and $\gamma-\mathrm{U}_{3} \mathrm{Mo}_{20} \mathrm{O}_{64}$ have also been examined by HREM technique [9].

The present investigation of the $\mathrm{UO}_{2}-\mathrm{MoO}_{2}-\mathrm{MoO}_{3}-\mathrm{WO}_{3}$ system illustrates that a combination of different techniques is essential to establish detailed structures of the different phases formed. This present contribution, which is the first in a series of articles on complex uranium oxides, containing molybdenum and tungsten will report mainly on the electron microscopy studies of phases built up of $\mathrm{ReO}_{3}$ - type slabs of widths corresponding to two, three, four and five octahedra. 

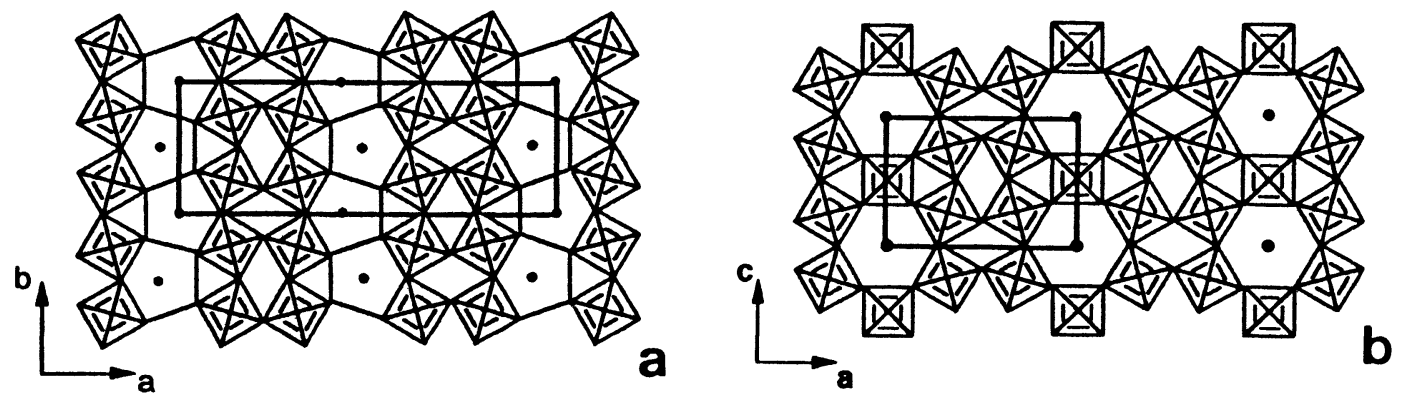

Fig. 1. - The idealized structures projected along the short crystal axis of a) $\beta-\mathrm{UMO}_{2} \mathrm{O}_{8}([001]$ zone), b) $\mathrm{UMo}_{5} \mathrm{O}_{16}$ ([010] zone). In the $\mathrm{UMo}_{10} \mathrm{O}_{32}$ structure, every tunnel is filled with strings of -O-U-O-U-, so that cornersharing hexagonal $\mathrm{UO}_{8}-$ bipyramids are formed, and every second tunnel is empty.

\section{Experimental.}

Samples of various compositions in different subsystems of the main system $\mathrm{UO}_{2}-\mathrm{MoO}_{2}-$ $\mathrm{MoO}_{3}-\mathrm{WO}_{3}$ were synthesised, by heating appropriate mixtures of binary oxides in evacuated silica tubes at $800-1000^{\circ} \mathrm{C}$ during $10-50$ days, as will be described in detail elsewhere. Almost all samples obtained were multiphasic. Each specimen was examined optically and a few crystals of similar habitus and colour were selected for X-ray and electron microscopy studies.

$\mathrm{X}$-ray powder photographs were taken in a focusing camera of Guinier-Hägg type, with monochromatized $\mathrm{CuK} \alpha_{1}$ radiation and using Si as an internal standard. Powder patterns were recorded both of the bulk sample and of the selected crystals. The unit cell parameters were refined by least-squares techniques. Single-crystal X-ray diffraction studies were also made, but these results will be published separately.

The selected crystals were investigated by high-resolution transmission electron microscopy, electron diffraction and EDS techniques. All electron microscopy specimens were prepared by crushing the selected crystals in an agate mortar under $n$-butanol and allowing a drop of the suspension to dry of a holey carbon support film. The grids were examined in a JEOL 200CX electron microscope, equipped with top-entry goniometer stage allowing tilt angles of $\pm 10^{\circ}$. The radius of the objective aperture used corresponded to $4.1 \mathrm{~nm}^{-1}$ in the reciprocal space. Theoretical images were calculated by using a local version of the SHRLI suite of programs [10]. A large number of fragments were also examined by electron diffraction in combination with EDS-analysis. This study was carried out with a JEOL 2000 FXII electron microscope, equipped with a LINK system.

\section{Results.}

\section{a) $\mathrm{UMo}_{5} \mathrm{O}_{16}$.}

A $50 \%$ substitution of $\mathrm{U}$ by $\mathrm{Mo}$ in $\beta-\mathrm{UMo}_{2} \mathrm{O}_{8}$ creates a phase $\mathrm{UMo}_{5} \mathrm{O}_{16}$ in the subsystem $\mathrm{UO}_{2}-\mathrm{MoO}_{2}-\mathrm{MoO}_{3}$. Selected crystals from a sample with the composition $\mathrm{UO}_{2}: \mathrm{MoO}_{2}$ : $\mathrm{MoO}_{3}=1: 1: 25$ were of brown colour. Figure 2a shows a HREM image of a thin crystal fragment of the $\mathrm{UMo}_{5} \mathrm{O}_{16}$ phase, recorded at a defocus value where the projected $U$ and Mo atoms yield white contrast. The unit cell parameters, refined from X-ray powder data are $a=9.9026 \AA$, $b=4.1340 \AA, c=7.1823 \AA$ and $\beta=90.20^{\circ}$. The length of the $a$-axis indicates a structure of the type shown in figure $1 \mathrm{~b}$, where all six-sided tunnels are filled with -U-O-U-O-strings so that rows of 
cornersharing hexagonal $\mathrm{UO}_{8}$-bipyramids are formed parallel to the $b$-axis. The stoichiometric composition of the model is $\mathrm{UMo}_{5} \mathrm{O}_{16}$.
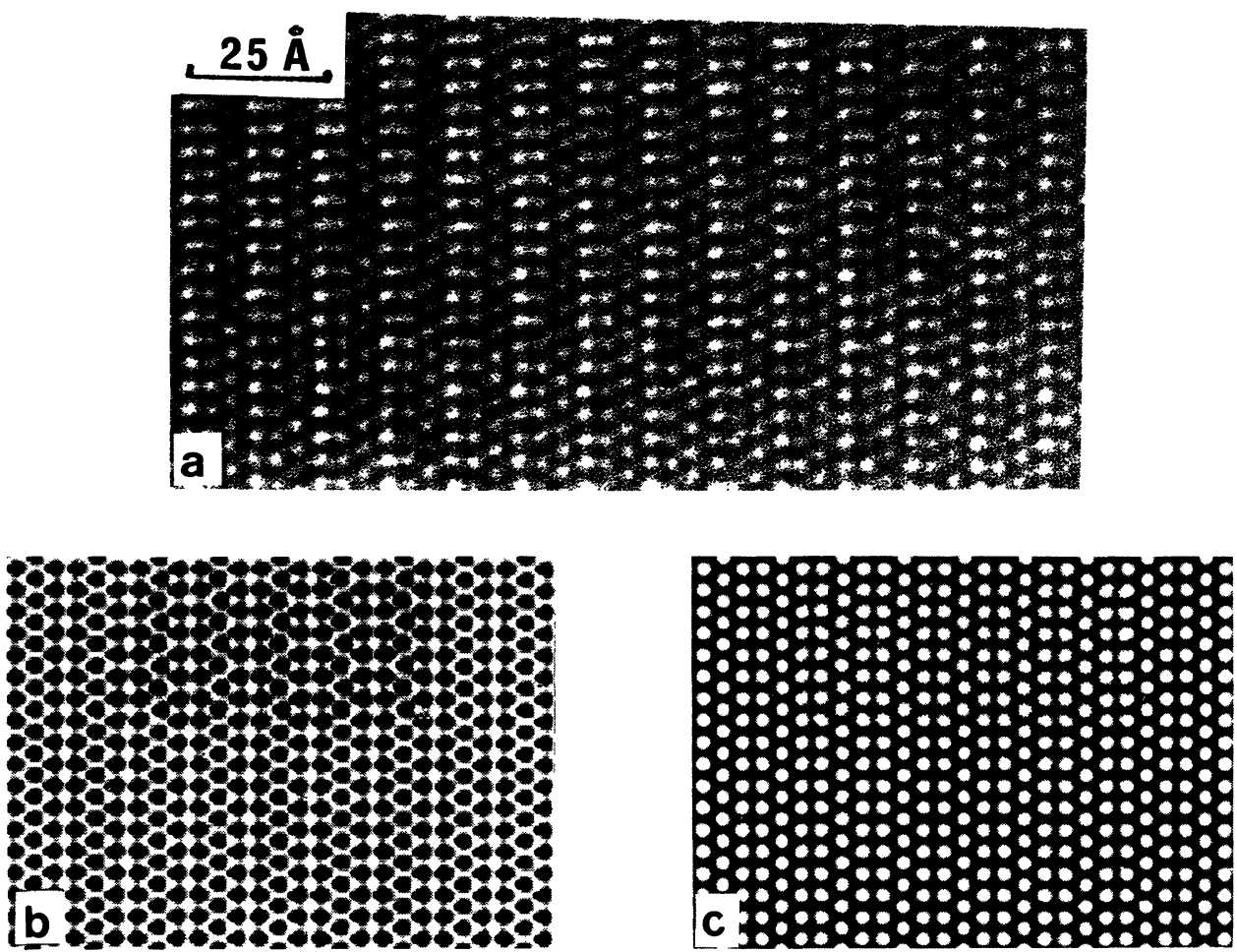

Fig. 2. - a) $\mathrm{HREM}$ image of $\mathrm{UMo}_{5} \mathrm{O}_{16}$ projected along [010]. b,c) Calculated images of the $\mathrm{UMo}_{5} \mathrm{O}_{16}$ structure with insets calculated for the $\beta-\mathrm{UMo}_{2} \mathrm{O}_{8}$ structure; (crystal thickness $\approx 20 \AA$ ), Defocus values; (b) $-500 . \AA,(c)-900 . \AA$. It is very hard to recognize the insets in these images, which shows that it is almost impossible to distinguish between these models from experimental images of thin crystals.

A set of calculated HREM images of the structure model in figure 1b, with full occupancy at all uranium and oxygen positions, is shown in figure 3a. The parameters used in the calculations were taken from the corresponding single-crystal $\mathrm{X}$-ray study of the $\mathrm{UMO}_{5} \mathrm{O}_{16}$ structure. Figure $3 b$ illustrates a set of calculated images based on the parameters given by Cremers et al. [7] for the $\beta-\mathrm{UMo}_{2} \mathrm{O}_{8}$ structure. Both sets of images clearly demonstrate that the heavy metal atoms in projection are imaged as black spots in a small region of defocus values around $-500 \AA$ and with reversed contrast in a region arround $-900 \AA$. For both cases the crystal thickness must be less than approximately $50 \AA$. For both structure models, there is good agreement between the experimental image in figure $2 \mathrm{a}$ and the calculated images for a defocus value of $-900 \AA$. In figures $2 \mathrm{~b}$ and $2 \mathrm{c}$, the calculated image of $\beta-\mathrm{UMo}_{2} \mathrm{O}_{8}$ has been inserted into the corresponding calculated image of the $\mathrm{UMo}_{5} \mathrm{O}_{16}$ structure model. These calculated images clearly show that for thin crystals (thickness $<50 \AA$ ) it is impossible to distinguish between these two models without considering information obtained by other methods. On the other hand, the calculations show that for thicker crystals the images should be different. However, at larger thicknesses the contrast does not correspond to individual rows of heavy atoms, and the $\mathrm{ReO}_{3}$-type pattern is not 


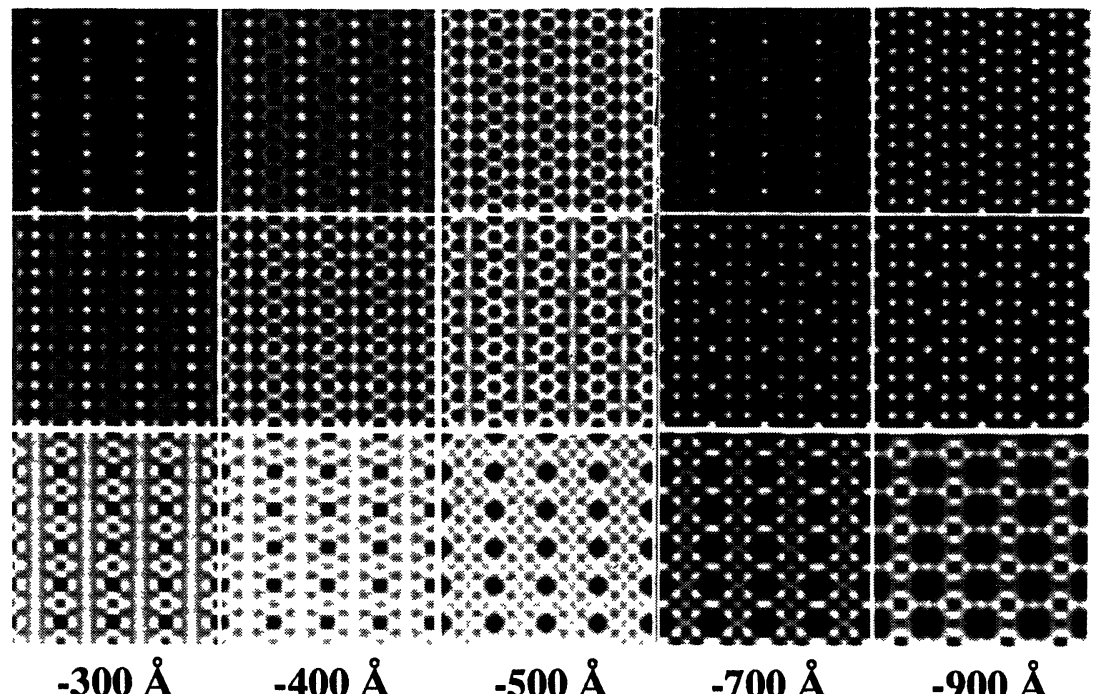

a)

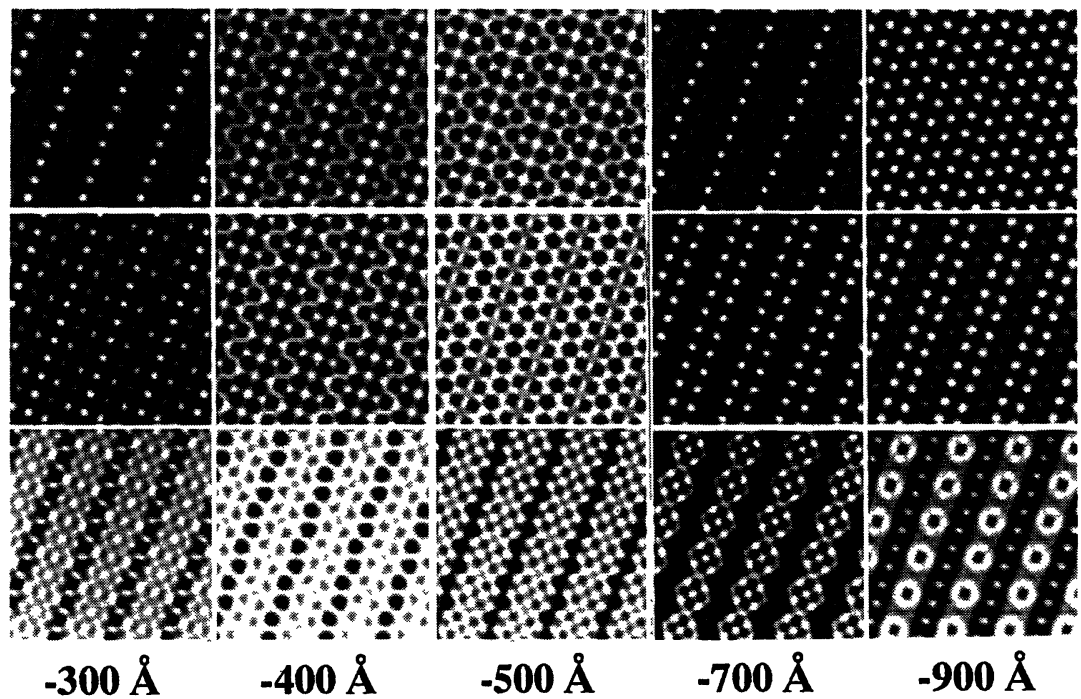

b)

Fig. 3. - a) Simulated images of the $\mathrm{UMo}_{5} \mathrm{O}_{16}$ structure. b) Simulated images of the $\beta-\mathrm{UMo}_{2} \mathrm{O}_{8}$ structure. Crystal thickness: first row $20 \AA$, middle row $40 \AA$, bottom row $60 \AA$. The defocus values are shown in the figure.

revealed, which makes a direct interpretation difficult. The contrast character in the micrograph of the thicker part of a fragment confirmed the $\mathrm{UMo}_{5} \mathrm{O}_{16}$ models, however.

b) $\mathrm{U}_{0.5}(\mathrm{Mo}, \mathrm{W})_{7} \mathrm{O}_{22}$.

Crystals of similar habitus and colour were selected from the bulk sample $\mathrm{UO}_{2}: \mathrm{MoO}_{3}$ : $\mathrm{WO}_{3}=1: 7: 4$. The unit cell dimensions derived from the ED pattern taken along the short crystal 
$c$-axis were $a \approx 27.1 \AA$ and $b \approx 7.2 \AA$. Later, the unit cell parameters were refined from X-ray powder data and found to be $a=27.227 \AA, b=7.2709 \AA$ and $c=3.9766 \AA$.

The contrast features in the HREM image (Fig. 4a) clearly indicate that the structure consists of slabs of $\mathrm{ReO}_{3}$-type. The slabs are infinite in two dimensions and three octahedra wide.
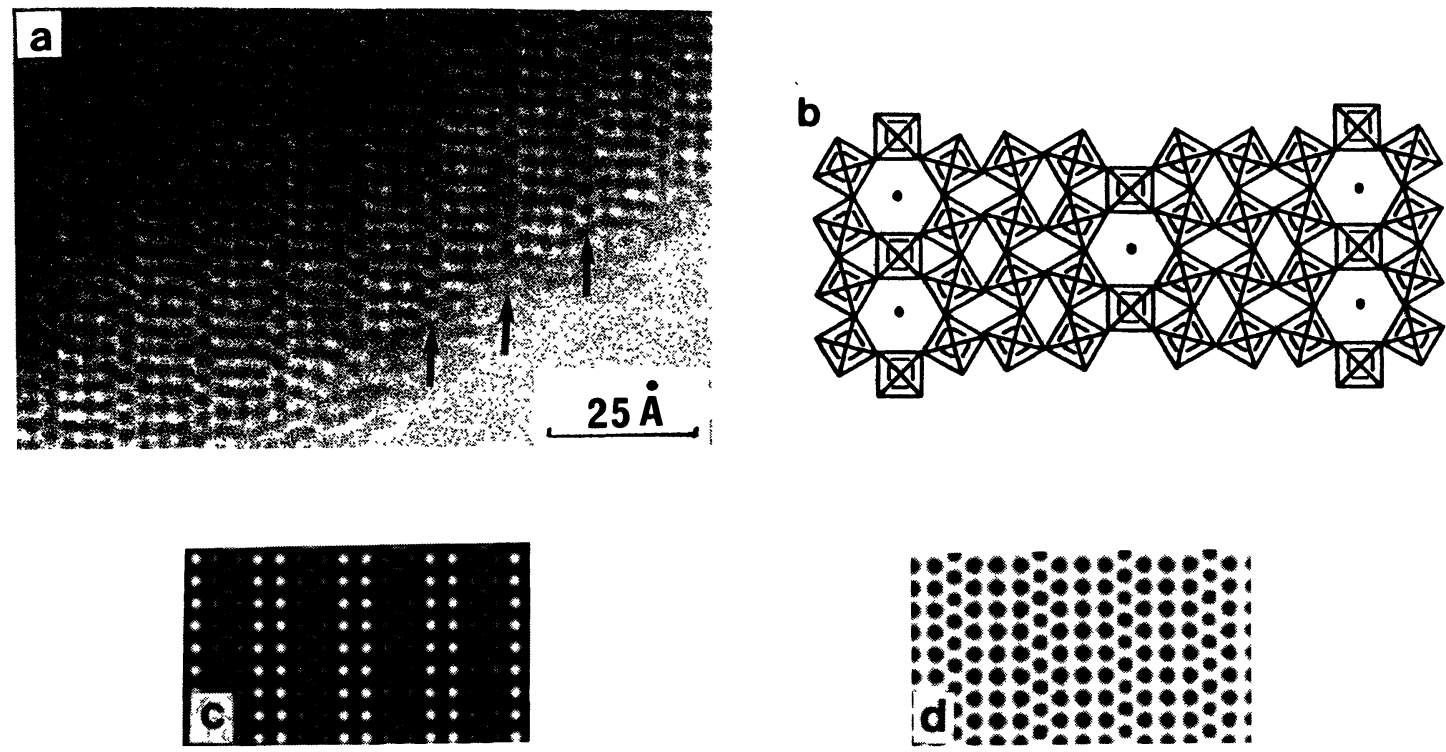

Fig. 4. - a) HREM image of a thin fragment of $\mathrm{U}_{0.5}(\mathrm{Mo}, \mathrm{W})_{7} \mathrm{O}_{22}$; b) Idealized structure model of $\left.\mathrm{U}_{0.5}(\mathrm{Mo}, \mathrm{W})_{7} \mathrm{O}_{22} ; \mathrm{c}, \mathrm{d}\right)$ Calculated images of the model in (b), crystal thickness $20 \AA$, defocus values $-400 \AA$ (c), $-500 \AA$ (d).

The micrograph also shows almost straight lines of dark spots of uniform size and intensity between the $\mathrm{ReO}_{3}$-type slabs (see arrows), making a straightforward interpretation of the contrast character difficult. The arrangement of dark spots can either be interpreted as an ordered arrangement of $\mathrm{MoO}_{6}-$ octahedra and hexagonal $\mathrm{UO}_{8}$ - bipyramids as in $\mathrm{UMo}_{5} \mathrm{O}_{16}$ or as a zigzag chain of edge-sharing pentagonal $\mathrm{UO}_{7}$-bipyramids such as existing in $\beta-\mathrm{UMo}_{2} \mathrm{O}_{8}$. The dimension of the $a$-axis and the contrast features in the HREM image suggest a structure such as that shown in figure $4 \mathrm{~b}$. With reference to the $\mathrm{UMo}_{5} \mathrm{O}_{16}$ structure, it seems likely that the Mo/Watoms occur in the $\mathrm{MO}_{6}$-octahedra, while $\mathrm{U}$ - and $\mathrm{O}$ - atoms are located in the six-sided tunnels, so that hexagonal $\mathrm{UO}_{8}$-bipyramids are formed. The network of corner-sharing $\mathrm{MO}_{6}-$ octahedra corresponds to a composition of $\mathrm{M}_{14} \mathrm{O}_{42}$, while full occupancy of the six-sided tunnels gives the composition $A_{2} M_{14} \mathrm{O}_{44}$. In order to yield electroneutrality of the structure, the composition of the examined phase should be $\mathrm{U}(\mathrm{Mo}, \mathrm{W}){ }_{14} \mathrm{O}_{44}$, which means that only half of the hexagonal bipyramids are occupied by U-atoms. This U-content is also in agreement with EDS results obtained from ten different crystal fragments. The Mo/W ratio was found to be about 0.89 from the EDS measurements. The composition of this phase should thus be close to $\mathrm{U}_{0.5} \mathrm{Mo}_{3.3} \mathrm{~W}_{3.7} \mathrm{O}_{22}$. The distributions of $U$ atoms and vacancies seem to be random, as no superstructure reflexion has been observed in the ED patterns.

A single crystal $\mathrm{X}$-ray investigation is under way. The results so far obtained verify the structure model shown in figure $4 \mathrm{~b}$. The central $\mathrm{Mo}$ and $\mathrm{W}$ atoms in the $M \mathrm{O}_{6}$-octahedra seem to be displaced from the plane $z=0$, so that a slightly puckerd arrangement of $M$-atoms in the 
$\mathrm{ReO}_{3}$-type slabs is obtained. Simulated HREM images of the structure model in figure $4 \mathrm{~b}$ were calculated by using the atom positions obtained from the single-crystal $x$-ray study. There is good agreement between the observed image (Fig. 4a) and the calculated images (Figs.4c and 4d).

The $\mathrm{U}_{0.5} \mathrm{Mo}_{3.3} \mathrm{~W}_{3.7} \mathrm{O}_{22}$ phase has not previously been observed in the $\mathrm{UO}_{2}-\mathrm{MoO}_{3}-\mathrm{WO}_{3}$ system. All ED patterns recorded of thin crystal fragments indicated a well-ordered phase, as all reflexion spots were sharp and no streaking occurred. The HREM images showed exclusively $\mathrm{ReO}_{3}$ - type slabs three $M \mathrm{O}_{6}$-octahedra wide. The image calculations showed that it is not possible to distinguish between the $U$ and Mo atom positions in the linkage planes between the $\mathrm{ReO}_{3}$-type slabs from the micrograph.

c) $\mathrm{U}(\mathrm{Mo}, \mathrm{W})_{4} \mathrm{O}_{14}$ and $\mathrm{U}_{0.5}(\mathrm{Mo}, \mathrm{W})_{11} \mathrm{O}_{34}$.

Electron microscopy studies of crystals selected from the bulk sample $\mathrm{UO}_{2}: \mathrm{MoO}_{3}: \mathrm{WO}_{3}=$ 1:3:11 yielded three distinct types of ED-pattern. Figure 5 illustrates that all these patterns are related to the same basic $\mathrm{ReO}_{3}$-type structure but with slightly different unit cell parameters. The unit cell parameters were calculated to be $a \approx 2 \times 17.5=35.0 \AA, b \approx 7.4 \AA, C$-centered (Fig. $5 \mathrm{a}$ ); $a \approx 2 \times 21.3=42.6 \AA, b \approx 7.4 \AA C$-centered (Fig. $5 \mathrm{~b}$ ) and $a \approx 21.3 \AA, b \approx 7.4 \AA$ (Fig. 5c). Note the relationship between figures $5 \mathrm{~b}$ and $5 \mathrm{c}$; in figure $5 \mathrm{~b}$ the $a$-axis is twice that in figure $5 \mathrm{c}$.
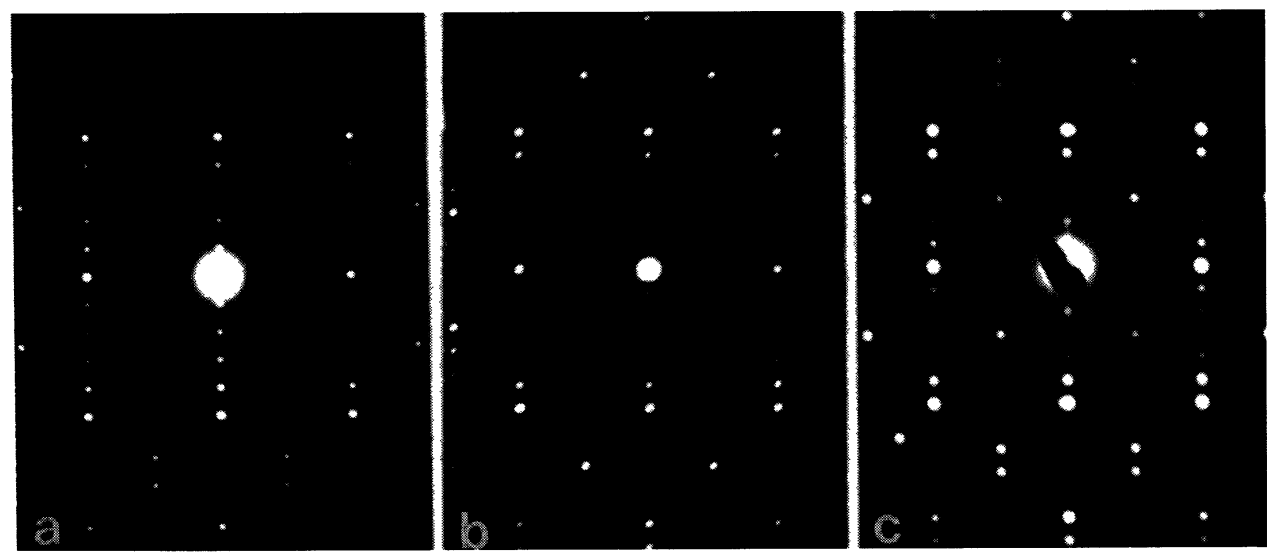

Fig. 5. - ED-patterns in [001] projection of a) $\left.\left.\mathrm{U}(\mathrm{Mo}, \mathrm{W})_{4} \mathrm{O}_{14} ; \mathrm{b}\right) \mathrm{U}_{0.5}(\mathrm{Mo}, \mathrm{W})_{11} \mathrm{O}_{34} ; \mathrm{c}\right) \mathrm{U}(\mathrm{Mo}, \mathrm{W})_{5} \mathrm{O}_{17}$.

The micrograph of the first phase (Fig. 6a) shows that the $\mathrm{ReO}_{3}-$ type slabs are four $\mathrm{MO}_{6}-$ octahedra wide. From an X-ray powder pattern the unit cell dimensions were found to be $a=35.007$ $\AA, b=7.3610 \AA$ and $c=4.0562 \AA$. The single crystal $\mathrm{X}$-ray investigation yielded the structure model in figure $6 \mathrm{~b}$. The structure can be described as built up of $\mathrm{ReO}_{3}$-type slabs four octahedra wide and linked by $\mathrm{U}$ - and $\mathrm{O}$-atoms so that a pleated edgesharing arrangement of pentagonal $\mathrm{UO}_{7}$-bipyramids is formed.

The HREM image in figure 7a shows an ordered crystal fragment. The corresponding ED pattern is identical to that shown in figure $5 \mathrm{~b}$. The square array of black spots represents cornersharing $\mathrm{MO}_{6}$-octahedra in $\mathrm{ReO}_{3}$-type slabs. The micrograph clearly shows that the slab width corresponds to five octahedra. The linkage plane between the slabs, which is imaged as an almost 

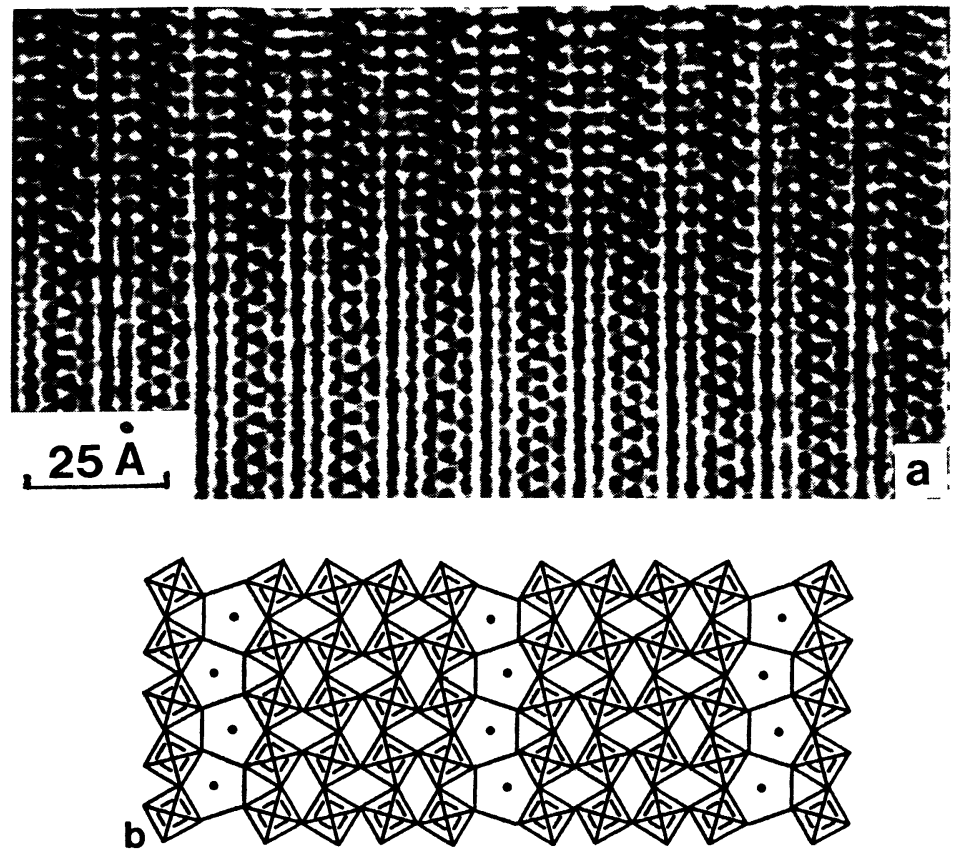

Fig. 6. - a) $\mathrm{HREM}$ image of $\mathrm{U}(\mathrm{Mo}, \mathrm{W})_{4} \mathrm{O}_{14}$. [001] projection, b) Idealized structure model of $\mathrm{U}(\mathrm{Mo}, \mathrm{W}) 4 \mathrm{O}_{14}$.

straight row of black spots, cannot be directly interpreted from the HREM image. However, considering the doubling of the $a$-axis, which is obvious from the ED pattern in figure $5 \mathrm{~b}$, it is most likely that the slabs are linked as in figure $1 b$. The row of black spots can thus be interpreted as an ordered arrangement of $\mathrm{MoO}_{6}-$ octahedra and hexagonal $\mathrm{UO}_{8}$-bipyramids. The corresponding structure model, projected along the short $c$-axis, is shown in figure $7 \mathrm{~b}$. This structure is homologous with the $\mathrm{U}_{0.5}(\mathrm{Mo}, \mathrm{W})_{7} \mathrm{O}_{22}$ phase above; only the widths of the $\mathrm{ReO}_{3}$-type slabs differ. The composition can be calculated to be $\mathrm{U}_{0.5}(\mathrm{Mo}, \mathrm{W})_{11} \mathrm{O}_{34}$. Charge balance requires that only half of the hexagonal bipyramids formed should be occupied by $\mathrm{U}$ atoms The $M \mathrm{O}_{6}$-octahedra are all assumed to be randomly occupied by Mo and W. From the thinner part of the crystal fragment in figure 7a, it can be seen that the intensity of the black spots along the linkage plane between the $\mathrm{ReO}_{3}$-type slabs varies. At a few places, marked by arrows, the spots are almost unobservable, which should be due to the presence of uranium vacancies. The $U$ vacancies seem to be randomly distributed in the structure, however, as no indications of streaking or superstructure reflexions have been observed so far. EDS-analysis of a few fragments with identical ED-patterns, as in figure 5b, indicate a low uranium content. The EDS- results so far obtained are all in agreement with the calculated composition, and they show that the most likely composition is close to $\mathrm{U}_{0.5} \mathrm{Mo}_{3} \mathrm{~W}_{8} \mathrm{O}_{34}=\mathrm{U}_{0.5}(\mathrm{Mo}, \mathrm{W})_{11} \mathrm{O}_{34}$. No crystal of the $\mathrm{U}_{0.5}(\mathrm{Mo}, \mathrm{W})_{11} \mathrm{O}_{34}$ phase, suitable for single-crystal $\mathrm{x}$-ray studies, has so far been found.

EDS-analysis of fragments giving the ED-pattern shown in figure $5 \mathrm{c}$, indicated a much higher uranium content than that of the $\mathrm{U}_{0.5}(\mathrm{Mo}, \mathrm{W}){ }_{11} \mathrm{O}_{34}$ phase. The composition of the fragment is closer to $\mathrm{U}(\mathrm{Mo}, \mathrm{W})_{5} \mathrm{O}_{17}$. 

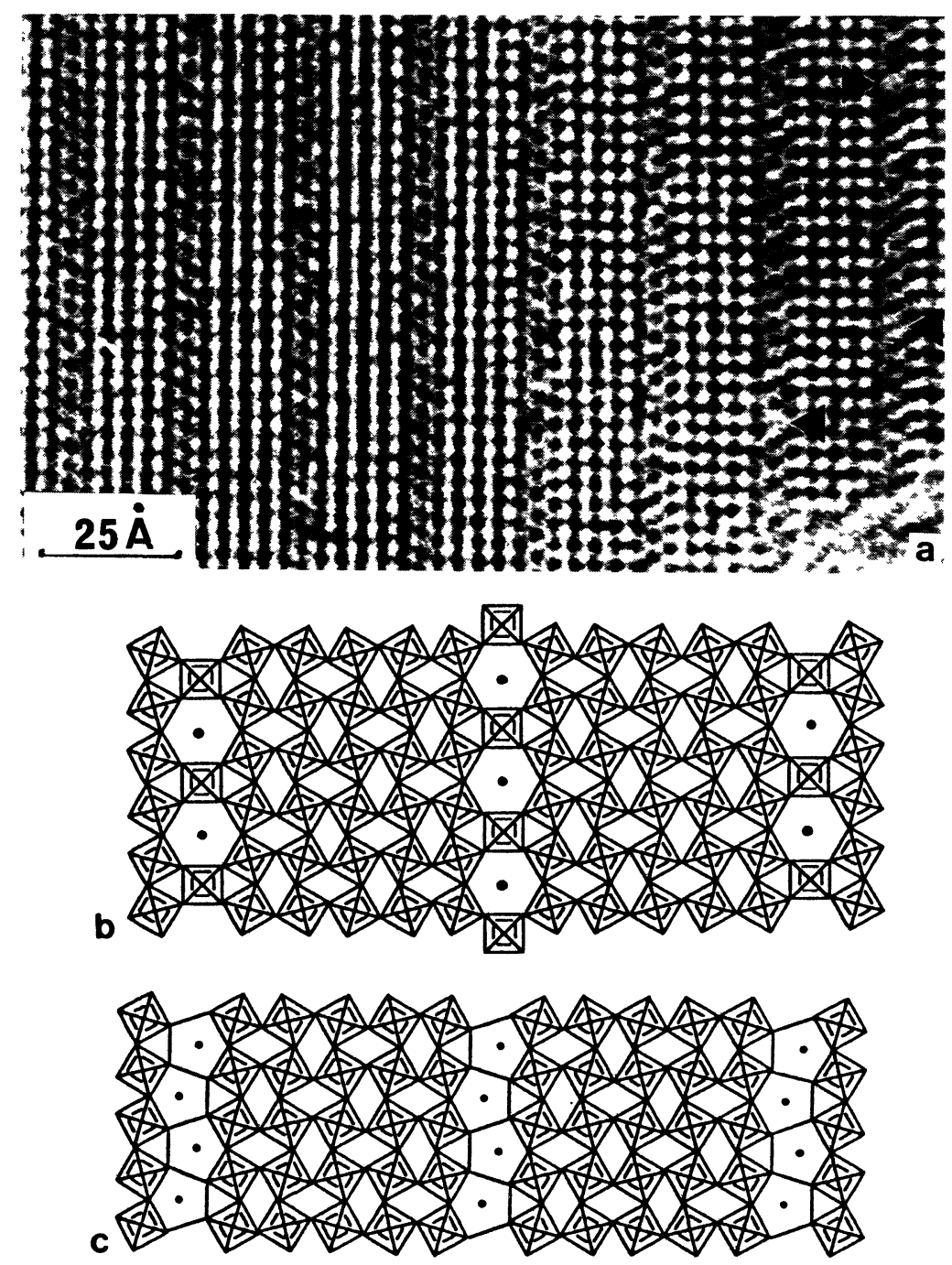

Fig. 7. - a) HREM image of a thin fragment of $\mathrm{U}_{0.5}(\mathrm{Mo}, \mathrm{W}){ }_{11} \mathrm{O}_{34}$, arrows mark almost empty six-sided tunnels. b) Idealized structure model of $\mathrm{U}_{0.5}(\mathrm{Mo}, \mathrm{W})_{11} \mathrm{O}_{34}$. c) Idealized structure model of $\mathrm{U}(\mathrm{Mo}, \mathrm{W})_{5} \mathrm{O}_{17}$.

d) $\mathrm{U}(\mathrm{Mo}, \mathrm{W})_{5} \mathrm{O}_{17}$.

X-ray diffraction data were collected from a single crystal selected from the $\mathrm{UO}_{2}: \mathrm{MoO}_{3}$ : $\mathrm{WO}_{3}=1: 1: 13$ sample. The structure determination resulted in the model shown in figure $7 \mathrm{c}$. From $x$-ray powder data the unit cell parameters were found to be $a=42.484 \AA, b=7.3823 \AA$ and $c=4.0363 \AA$. The structure is related to that obtained for the $\mathrm{U}_{0.5}(\mathrm{Mo}, \mathrm{W})_{11} \mathrm{O}_{34}$ phase above. Both structures contain slabs that are five $\mathrm{MO}_{6}$-octahedra wide, but the atom arrangements between the slabs are different. In figure 7c, only $\mathrm{U}$ - and $\mathrm{O}$-atoms are located between the slabs in such a way that a pleated, edgesharing chain of pentagonal $\mathrm{UO}_{7}$-bipyramids is formed, identi- 
cal to that previously observed in the $\beta-\mathrm{UMo}_{2} \mathrm{O}_{8}$ structure (Fig. 1a). The single-crystal X-ray results strongly support this arrangement. The unit cell content in figure $7 \mathrm{c}$ corresponds to the stoichiometric formula $\mathrm{U}(\mathrm{Mo}, \mathrm{W})_{5} \mathrm{O}_{17}$. All $\mathrm{U}$-atom positions in the linkage plane are fully occupied by U-atoms. The X-ray study also showed a puckered arrangement of the metal atoms. The displacement, $\pm \Delta z$, of $M$-atoms from the $z=0$ plane in the $\mathrm{ReO}_{3}$-type slabs doubles the a-axis.

Some of the selected crystals were also used for electron microscopy study. All electron diffraction patterns recorded were identical to that shown in figure $5 \mathrm{c}$, with cell dimensions $a \approx 21.4 \AA$ and $b \approx 7.4 \AA$. Because of systematic $h k 0$ absences, the periodicity along $a$ shows up as half of the actual value. EDS-analysis of twenty fragments, indicated that a likely composition is close to $\mathrm{UMo}_{0.8} \mathrm{~W}_{4.2} \mathrm{O}_{17}$.

The EDS-analysis in combination with the corresponding electron diffraction study and the $\mathrm{X}$-ray results, showed that two different, but closely related phases exist, viz. $\mathrm{U}(\mathrm{Mo}, \mathrm{W})_{5} \mathrm{O}_{17}$ and $\mathrm{U}_{0.5}(\mathrm{Mo}, \mathrm{W})_{11} \mathrm{O}_{34}$. One phase has a slightly higher uranium content than the other, but they have almost identical unit cell dimensions.

e) $\mathrm{U}_{0.5}(\mathrm{Mo}, \mathrm{W})_{9} \mathrm{O}_{28}$.

The last example illustrates ordered vacancies. Electron diffraction patterns of selected crystals from the bulk sample $\mathrm{UO}_{2}: \mathrm{MoO}_{3}: \mathrm{WO}_{3}=1: 3: 8$ were similar to the patterns shown in figure 5 . Figure 8a illustrates that weak superstructure reflexion spots doubles both the $a-$ and $c$-axes of the unit cell.

The unit cell parameters obtained from figure $8 \mathrm{a}$ are $a \approx 2 \times 17.6 \approx 35.2 \AA$ and $b \approx 2 \times 7.2 \approx$ 14.4 $\AA$. The micrograph in figure $8 \mathrm{~b}$ shows that the $\mathrm{ReO}_{3}$-type slabs are four octahedra in width, and large white spots can be seen regularly distributed (three black spots, one white spot) along the connection planes between the slabs. At a few places, disorder can be observed. The dimensions of the subcell $\left(a_{\text {sub }} \approx 17.6 \AA\right.$ and $b_{\text {sub }} \approx 7.2 \AA$ ) and the contrast features in the HREM images indicate a basic framework structure: a network of cornersharing $\mathrm{MO}_{6}$-octahedra arranged so that six-sided tunnel are formed, and every second tunnel is filled with -O-U-O-U-O-strings as in figure $8 \mathrm{c}$. The weak superstructure reflexion spots observed in the ED-pattern are caused by ordering of the filled tunnels. The white spots in figure $8 \mathrm{~b}$ correspond to empty tunnels. The composition of the structure model in figure $8 \mathrm{c}$ is $\mathrm{U}_{0.5}(\mathrm{Mo}, \mathrm{W})_{9} \mathrm{O}_{28}$.

\section{Discussion.}

The results obtained above are summarized in table I. The structures can be considered as belonging to two homologous series of phases, both built up of $\mathrm{ReO}_{3}-$ type slabs of variable width, but with the slabs mutually connected in different ways.

The structures denotes $(n)-\mathrm{PB}$ in table I can be ascribed to a homologous series with the general formula UO $\cdot M_{n} \mathrm{O}_{3 n+1}$, where $n$ represents the number of $M \mathrm{O}_{6}-$ octahedra across the $\mathrm{ReO}_{3}$-type slab. The slabs are interleaved with -U-O-U-O- atom rows so that chains of edgesharing pentagonal $\mathrm{UO}_{7}-$ bipyramids $(\mathrm{PB}=$ pentagonal bipyramid $)$ are formed. All uranium positions are fully occupied by uranium atoms. The $\mathrm{UMoO}_{5}$ phase, which is isostructural with $\mathrm{UVO}_{5}[11]$, is the first member $(n=1)$ of this series and will thus be denoted (1)-PB, while the $\beta-\mathrm{UMo}_{2} \mathrm{O}_{8}$ phase corresponds to (2)-PB. For the members (4)-PB and (5)-PB described above, the Mo-atoms have to a large extent been replaced by W-atoms. Alternatively, this set of structures can be considered as intergrowths of $\mathrm{UVO}_{5}-$ and $\mathrm{ReO}_{3}$ - type structure elements.

The other class of structures observed so far in the examined subsystems, denoted $(n)-\mathrm{HB}$ in 

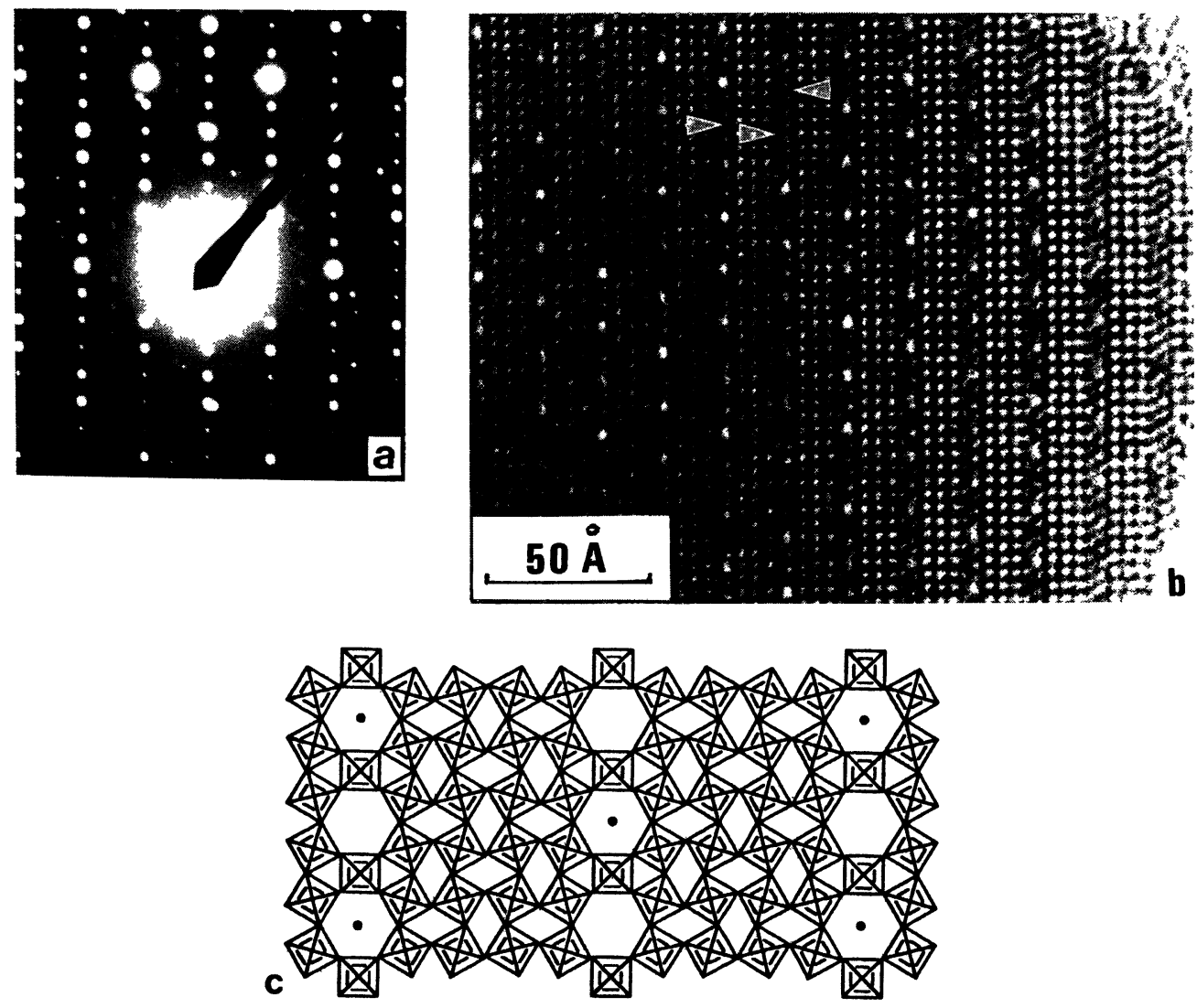

Fig. 8. - a) ED-pattern, [001] projection, of $\mathrm{U}_{0.5}(\mathrm{Mo}, \mathrm{W})_{9} \mathrm{O}_{28}$. b) Corresponding micrograph of a thin crystal fragment. Arrows mark disorder in the filling of the six-sided tunnels. c) Idealized structure model of $\mathrm{U}_{0.5}(\mathrm{Mo}, \mathrm{W})_{9} \mathrm{O}_{28}$.

Table I.

\begin{tabular}{|l|c|c|c|l|l|}
\hline \multicolumn{1}{|c|}{ Compound } & $\begin{array}{c}\text { Number of octahe- } \\
\text { dra in the } \mathrm{ReO}_{3}- \\
\text { type slab }(n)\end{array}$ & $\begin{array}{c}\text { Coordination } \\
\text { of U - atom }\end{array}$ & $\begin{array}{c}\text { Occupancy } \\
\text { of U in } \\
\text { bipyramids }\end{array}$ & $\begin{array}{l}\text { Denotation } \\
\text { of structure }\end{array}$ & References \\
\hline $\mathrm{UMoO}_{5}$ & 1 & 7 & 1.0 & $(1)-\mathrm{PB}$ & {$[11]$} \\
$\beta-\mathrm{UMO}_{2} \mathrm{O}_{8}$ & 2 & 7 & 1.0 & $(2)-\mathrm{PB}$ & {$[7]$} \\
$\mathrm{U}(\mathrm{Mo}, \mathrm{W})_{4} \mathrm{O}_{14}$ & 4 & 7 & 1.0 & $(4)-\mathrm{PB}$ & This study, [8] \\
$\mathrm{U}(\mathrm{Mo}, \mathrm{W})_{5} \mathrm{O}_{17}$ & 5 & 7 & 1.0 & $(5)-\mathrm{PB}$ & This study, [8] \\
& 2 & 8 & 1.0 & $(2)-\mathrm{HB}$ & This study \\
$\mathrm{UMO}_{5} \mathrm{O}_{16}$ & 2 & 8 & 0.75 & $(2)-\mathrm{HB}$ & {$[4]$} \\
$\alpha-\mathrm{U}_{3} \mathrm{Mo}_{20} \mathrm{O}_{64}$ & 2 & 8 & 0.50 & $(2)-\mathrm{HB}$ & {$[5]$} \\
$\mathrm{UMO}_{10} \mathrm{O}_{32}$ & 3 & 8 & 0.50 & $(3)-\mathrm{HB}$ & This study \\
$\mathrm{U}_{0.5}(\mathrm{Mo}, \mathrm{W})_{7} \mathrm{O}_{22}$ & 4 & 8 & 0.50 & $(4)-\mathrm{HB}$ & This study \\
$\mathrm{U}_{0.5}(\mathrm{Mo}, \mathrm{W})_{9} \mathrm{O}_{28}$ & 5 & 8 & 0.50 & $(5)-\mathrm{HB}$ & This study \\
$\mathrm{U}_{0.5}(\mathrm{Mo}, \mathrm{W})_{11} \mathrm{O}_{34}$ & 5 & & &
\end{tabular}


table I, can be considered as a homologous series with the general formula $\mathrm{U}_{1-x} \square_{x} \mathrm{O} \cdot m M \mathrm{O}_{3}$ ( $\square=$ vacancy), with $m=2 n+1$, where $n$ is the number of octahedra across the $\mathrm{ReO}_{3}$-type slab. The structures can be described as built up of a basic network of cornersharing $\mathrm{MO}_{6}-\mathrm{octahedra}$ arranged so as to form slabs of six-sided tunnels separated by $\mathrm{ReO}_{3}-$ type slabs of width $n$. The former slabs are HTB (hexagonal tungsten bronze) elements one tunnel row wide. Thus, the basic structure can be regarded as an intergrowth between slabs of HTB-type and $\mathrm{ReO}_{3}$-type structures. Chains of -O-U-O-U-O- enter the six-sided tunnels and thus transform them to chains of cornersharing hexagonal $\mathrm{UO}_{8}-$ bipyramids $(\mathrm{HB}=$ hexagonal bipyramids), running along the short crystal axis. In the $\mathrm{UMo}_{5} \mathrm{O}_{16}\left(\mathrm{UO} \cdot 5 \mathrm{MoO}_{3}\right)$ structure, all uranium atom positions are fully occupied $(x=0)$, while in the $\alpha-\mathrm{U}_{3} \mathrm{Mo}_{20} \mathrm{O}_{64}$ structure $(x=0.25) 25 \%$ of the uranium positions are vacant. The formula $\alpha-\mathrm{U}_{3} \mathrm{Mo}_{20} \mathrm{O}_{64}$ can thus be rewritten as $\alpha-\mathrm{U}_{0.75} \square_{0.25} \mathrm{O} \cdot 5 \mathrm{MoO}_{3}$. Other phases are formed where only half of the uranium atom positions are occupied $(x=0.5)$. The $\mathrm{UMo}_{10} \mathrm{O}_{32}$ structure in figure $1 \mathrm{~b}$ can be formulated as $\mathrm{U}_{0.5} \square_{0.5} \mathrm{O} \cdot 5 \mathrm{MoO}_{3}$. As can be seen from table I, UMo $\mathrm{UO}_{16}, \alpha-\mathrm{U}_{3} \mathrm{Mo}_{20} \mathrm{O}_{64}$ and $\mathrm{UMo}_{10} \mathrm{O}_{32}$ are all denoted (2)-HB, since their basic framework structures are the same; but they differ in the degree of filling of the hexagonal $\mathrm{UO}_{8}$-bipyramids. Replacement of molybdenum by tungsten creates larger $\mathrm{ReO}_{3}$-type slabs. The phases with $n=3,4$ and 5 have been reported above. The (4)-HB structure contained ordered vacancies. The creation of randomly distributed vacancies in the structure might indicate that $\mathrm{UO}_{2}$-groups are formed in the structures. An average uranium content in the hexagonal bipyramids, $x<0.5$, have not so far been observed. This might also indicate that $(\mathrm{O}-\mathrm{U}-\mathrm{O})^{2+}$ -groups should be present in the examined phases.

All structure models clearly show that the $\mathrm{ReO}_{3}$-type slabs consist of tilted octahedra. In the homologous series UO $\cdot M_{n} \mathrm{O}_{3 n+1},((n)-\mathrm{PB})$, members with $n=$ odd have a cell with the $a$-axis doubled, whereas the doubling is seen for $n=$ even in the other homologous series $\mathrm{U}_{1-x} \square_{x} \mathrm{O} \cdot m M \mathrm{O}_{3}((n)-\mathrm{HB})$. In the latter case, because of the tilt of the octahedra, the six-sided tunnels in two adjacent rows will be at the same $y$ level if there is an even number of octahedra between the rows, as in the $\mathrm{UMo}_{5} \mathrm{O}_{16}$. (2)- $\mathrm{HB}$, and $\mathrm{U}_{0.5}(\mathrm{Mo}, \mathrm{W})_{9} \mathrm{O}_{28}$, (4)- $\mathrm{HB}$, structures. On the other hand, two adjacent rows with six-sided tunnels will be displaced by $\Delta y=1 / 2$ relative to each other, if there is an odd number in the $\mathrm{ReO}_{3}$-type slabs, as in $\mathrm{U}_{0.5}(\mathrm{Mo}, \mathrm{W})_{7} \mathrm{O}_{22},(3)-\mathrm{HB}$, and $\mathrm{U}_{0.5}(\mathrm{Mo}, \mathrm{W}){ }_{11} \mathrm{O}_{34},(5)-\mathrm{HB}$.

Intergrowth between structures of the two homologous series $\mathrm{UO} \cdot M_{n} \mathrm{O}_{3 n+1}((n)-\mathrm{PB})$ and $\mathrm{U}_{1-x} \square_{x} \mathrm{O} \cdot m \mathrm{O}_{3}((n)-\mathrm{HB})$, modelled in figure 9, might easily occur. Theoretical image calculations have shown that such intergrowth would be difficult to observe in HREM images of thin regions. However, it seems likely that this might occur as local defects. Such local defects would have only a minor influence on the total composition.

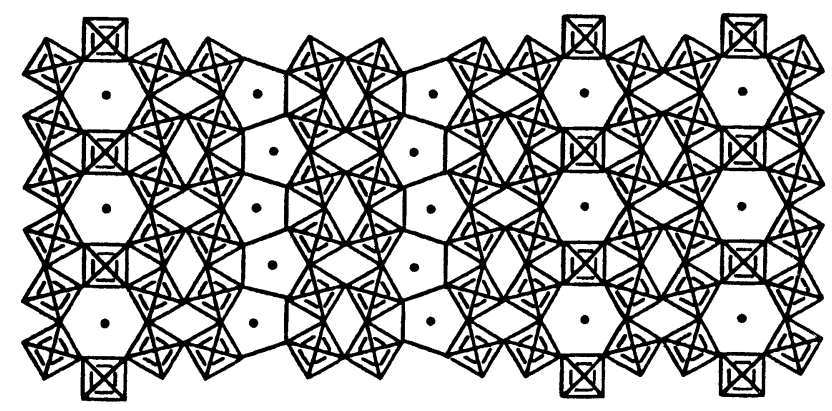

Fig. 9. - Idealized structure model showing hypothetical intergrowth of the $\mathrm{UMo}_{5} \mathrm{O}_{16}$ and $\beta-\mathrm{UMo}_{2} \mathrm{O}_{8}$ structures. 
When the basic structure of the $\mathrm{U}_{1-x} \square_{x} \mathrm{O} \cdot m M \mathrm{O}_{3}$ family of homologous phases is considered as an intergrowth between slabs of HTB-elements, one tunnel row wide, and the $\mathrm{ReO}_{3}-$ type structure, then the resemblance to the intergrowth tungsten bronzes (ITB) [12] is obvious. In the ITB bronzes, alkali atoms enter the six-sided tunnels while in the uranium compounds -U-O-U-Ostrings enter the tunnels and thus transform them into cornersharing hexagonal $\mathrm{UO}_{8}$-bipyramids. ITB bronze structures, where slabs of HTB-elements that are just one tunnel row wide are intergrown with $\mathrm{ReO}_{3}$-type regions, have been observed in a few samples with low alkali content e.g. $\mathrm{Cs}_{0.03} \mathrm{WO}_{3}$ and $\mathrm{Cs}_{0.05} \mathrm{WO}_{3}[12,13]$ and also in $\mathrm{Ba}_{0.04} \mathrm{WO}_{3}, \mathrm{~Pb}_{0.04} \mathrm{WO}_{3}$ and $\mathrm{Sn}_{0.04} \mathrm{WO}_{3}$ [14]. The $\mathrm{ReO}_{3}$-type slabs are wider for the ITB-bronzes (7-11 octahedra in the slabs) than for the related uranium phases presented above. For the ITB bronzes, intergrowth between various members of the homologous series occur frequently.

The ED-patterns of the $\mathrm{U}(\mathrm{Mo}, \mathrm{W})_{4} \mathrm{O}_{14}$ and $\mathrm{U}(\mathrm{Mo}, \mathrm{W})_{5} \mathrm{O}_{17}$ phases shown in figure 5a and 5c are similar to those previously published for $\mathrm{UW}_{4} \mathrm{O}_{14}$ and $\mathrm{UW}_{5} \mathrm{O}_{17}(8)$. Our single-crystal x-ray results given above for the $\mathrm{U}(\mathrm{Mo}, \mathrm{W})_{5} \mathrm{O}_{17}$ structure have confirmed the suggestion by Zakharov et al. that the "tungsten" atoms are shifted from the centre of the octahedra to form puckered layers, causing a doubling of the unit cell. However, it seems likely that some of the W-atoms in the $\mathrm{UW}_{4} \mathrm{O}_{14}$ and $\mathrm{UW}_{5} \mathrm{O}_{17}$ crystals studied by Zakharov et al. might have been replaced by Mo-atoms, since they were taken from a multiphasic sample of composition $\mathrm{UMoW}_{13} \mathrm{O}_{44}$.

\section{Acknowledgements.}

We wish to express our thanks to Professor L. Kihlborg for valuable comments on the manuscript. V.T. acknowlegdes fellowship from the Swedish Institute. Thanks are also due to Mr. Mats Sundberg for valuable help with drawing of the idealized structure models. This investigation has been financially supported by the Swedish Natural Science Research Council.

\section{References}

[1] KovBA L.M. and TRUNOV V.K., Radiokhimiya 7 (1964) 316; Engl. trans. Radiochemistry USSR Jerusalem 7 (1964) 314.

[2] PAilleret P., C.R.Acad. Sci. 265 (1967) 85.

[3] KoVBA L.M., Radiokhimiya 13 (1971) 909; Engl. trans: Radiochemistry USSR Jerusalem 13 (1971) 940.

[4] SEREZHKIN V.N., KoVBA L.M. and TRUNOV V.K., Kristallografiya 18 (1973) 961.

[5] SEREZHKIN V.N., KOVBA L.M. and TRUNOV V.K., Kristallografiya 19 (1974) 379.

[6] SEREZHKIN V.N., RONAMI G.N., KovBA L.M. and TRuNOV V.K., J. Inorg. Chem. (Russ.) 19 (1974) 1036.

[7] Cremers T.L., Eller P.G., Penneman R.A. and Herrick C.C., Acta Cryst. C39 (1983) 1163.

[8] ZAKHAROV N.D., GRIBELUK M.A., VAINSHTEIN B.K., ROZANOVA O.N., UCHIDA K. and HORIUCHI S., Acta Cryst. B39 (1983) 575.

[9] ZaKhaROV N.D., GRIBEluK M.A., VAINSTEIN B.K., KovBa L.M. and HoRIUCHI S., Acta Cryst. A44 (1988) 821.

[10] O'KEEFE M., BUSECK P.R. and IIJIMA S., Nature (London) 274 (1978) 322.

[11] CheVAlier R. and GASPERIN M., Bull. Soc. Fr. Minéral Crist. 93 (1970) 18.

[12] HuSSAIN A. and KiHLBORG L., Acta Cryst. A32 (1976) 551.

[13] Kinlborg L., Chem. Scr. 14 (1978-79) 187.

[14] DobSON M.M., HUTCHISON J.L., TilleY R.J.D. and WaTTS K.A., J. Solid State Chem. 71 (1987) 47. 